\title{
Erratum to: Allogeneic Haematopoietic Stem Cell Transplantation as Therapy for Chronic Granulomatous Disease-Single Centre Experience
}

Jolanta Goździk • Anna Pituch-Noworolska • Szymon Skoczeń • Wojciech Czogała • Anna Wedrychowicz • Jarosław Baran • Aleksandra Krasowska-Kwiecień •

Oktawiusz Wiecha • Marek Zembala

Published online: 20 October 2011

(C) Springer Science+Business Media, LLC 2011

Erratum to: J Clin Immunol (2011) 31:332-337

DOI: $10.1007 / \mathrm{s} 10875-011-9513-y$

Some results of this paper were analyzed and presented by Dr. Anna Wędrychowicz, who should be considered an author of the above.

The online version of the original article can be found at http://dx.doi. org/10.1007/s10875-011-9513-y.

J. Goździk $(\bowtie) \cdot$ S. Skoczeń $\cdot$ W. Czogała

A. Krasowska-Kwiecień $\cdot$ O. Wiecha

Transplantation Centre, University Children's Hospital,

265 Wielicka Street,

30-633 Cracow, Poland

e-mail: jgozdzik@cm-uj.krakow.pl

J. Goździk $\cdot$ A. Pituch-Noworolska $\cdot$ S. Skoczeń $\cdot$ J. Baran •

A. Krasowska-Kwiecień $\cdot$ M. Zembala

Department of Clinical Immunology and Transplantation,

Polish-American Institute of Paediatrics, Jagiellonian University,

Medical College,

Cracow, Poland

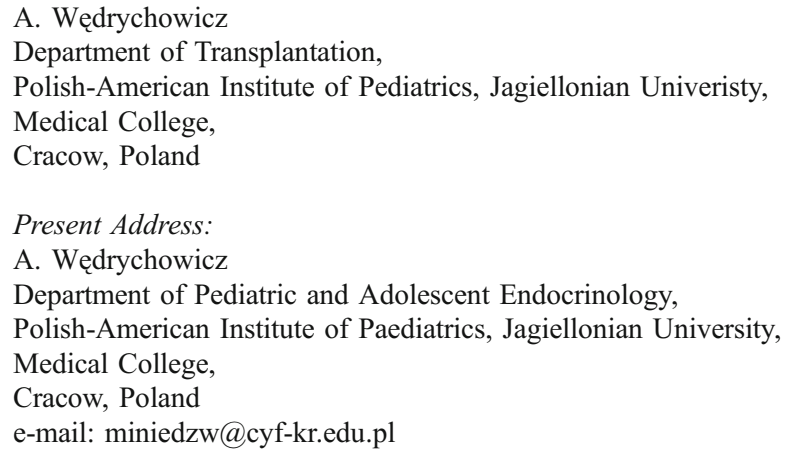

